\title{
КЛІНІКО-ІМУНОЛОГІЧНІ ТА АДАПТАЦІЙНІ ПОКАЗНИКИ ПРИ ЦЕРЕБРОВАСКУЛЯРНИХ ЗАХВОРЮВАННЯХ
}

\author{
Степаненко І. В., Попова І. Ю.
}

\section{ВСТУП}

Цереброваскулярні захворювання (ЦВ3) поряд 3 ішемічною хворобою серця та онкологічними захворюваннями належать до трьох основних причин інвалідності та смертності населення більшості країн світу. 3 багатьох захворювань ЦНС цереброваскулярна патологія все ще залишається ведучою ${ }^{1,2}$, і серед різних груп населення вона складає в середньому $38 \%{ }^{3}$. Особливе значення це має для України, де частота ЦВЗ більша в 2-4 рази порівняно 3 іншими країнами ${ }^{4,5,6}$, а захворюваність на мозковий інсульт (MI) найвища в Європі ${ }^{7,8}$. Попри певні досягнення в ангіоневрології, за даними різних авторів після інсульту протягом року гине до $48 \%$ хворих, а до $80 \% 3$ тих, що залишились живими, стають

${ }^{1}$ Мищенко Т.С. Эпидемиология цереброваскулярных заболеваний и организация помощи больным с мозговым инсультом в Украине. Украӥнський вісник психоневрології. 2017. Т. 25(1)

${ }^{2}$ Currie C., Morgan C., Gill L., et al. Epidemiology and costs of acute hospital care for cerebrovascular disease in diabetic and nondiabetic populations. Stroke. 1997. V. 28, № 6 .

3 Зозуля І.С., Зозуля А.І. Епідеміологія цереброваскулярних захворювань в Україні. Український медичний часопис. 2011. № 5(85)

${ }^{4}$ Мищенко Т.С. Эпидемиология цереброваскулярных заболеваний и организация помощи больным с мозговым инсультом в Украине. Український вісник психоневрології. 2017. Т. 25(1)

${ }^{5}$ Vemmos K., Bots M., Tsibouris P., et al. Stroke incidence and fatality in Southern Grecce. Stroke. 1999. V.30, № 2

${ }^{6}$ Регіональні особливості рівня здоров'я народу України: аналітичностатистичний посібник. Київ, 2013.

7 Мищенко Т.С. Эпидемиология цереброваскулярных заболеваний и организация помощи больным с мозговым инсультом в Украине. Український вісник психоневрологіï. 2017. Т. 25(1).

${ }^{8}$ Мищенко Т.С. Анализ состояния распространенности, заболеваемости и смертности от цереброваскулярних заболеваний в Украине. Судинні захворювання головного мозку. 2007. 
інвалідами, і лише 8-10\% повертаються до праці ${ }^{9,10,11,12}$. За даними BO3, вік кожного четвертого інваліда внаслідок судинного ураження мозку не перевищує 45 років (World Health Organization, 2004). Поширеність судинно-мозкових захворювань в нашій країні за 15 років зросла у 4,4 рази ${ }^{13,14}$, а за останні роки в 1,2 рази $^{15,16}$. При цьому підвищилась частота як інсультів та транзиторних порушень мозкового кровообігу (ТПМК) ${ }^{17}$, так $\mathrm{i}$ хронічних, повільно прогресуючих форм судинної патології головного мозку, які з часом можуть призвести до розвитку деменції, вплинути на тривалість і якість життя. Як свідчать дані статистики MO3 України, МI та ТПМК займають тільки 5\%, іншу частину складають хронічні порушення мозкового кровообігу (ХПМК), до яких належить і дисциркуляторна енцефалопатія (ДЕП) або хронічна ішемія мозку (XIM), яка зумовлює зростання кількості

${ }^{9}$ Гусев Е.И., Боголепова А.Н. Депрессивные расстройства у больных, перенесших инсульт. Журнал неврологии и психиатрии им. С.С. Корсакова. 2008. Вып. 22: Инсульт, приложение к журналу.

${ }^{10}$ Віничук С.M., Фартушна О.С. Епідеміологія транзиторних ішемічних атак у структурі гострих порушень мозкового кровообігу в Україні та інших країнах. Міжнародний неврологічний журнал. 2017. № 5(91).

${ }^{11}$ Хобзей Н.К., Голик В.А., Гондуленко Н.А., Мищенко Т.С. Особенности эпидемиологии инвалидности при заболеваниях нервной системы в Украине. Міжнародний неврологічний журнал. 2011. № 5(43)

${ }^{12}$ Калашников Н.В., Кузнецова С.М., Ена Л.М., и др. Анализ эпидемиологической ситуации с церебральной сосудистой патологией и некоторыми другими болезнями системы кровообращения, сложившейся в Украине в 1980-2001 гг. Журнал АМН України. 2004. № 4.

13 Зозуля І.С., Зозуля А.І. Епідеміологія цереброваскулярних захворювань в Україні. Український медичний часопис. 2011. № 5(85).

${ }^{14}$ Калашников Н.В., Кузнецова С.М., Ена Л.М., и др. Анализ эпидемиологической ситуации с церебральной сосудистой патологией и некоторыми другими болезнями системы кровообращения, сложившейся в Украине в 1980-2001 гг. Журнал АМН України. 2004. № 4.

${ }^{15}$ Мищенко Т.С. Эпидемиология цереброваскулярных заболеваний и организация помощи больным с мозговым инсультом в Украине. Украӥнський вісник психоневрології. 2017. Т. 25(1).

${ }^{16}$ Регіональні особливості рівня здоров'я народу України: аналітичностатистичний посібник. Київ, 2013.

${ }^{17}$ Віничук С.М., Фартушна О.Є. Епідеміологія транзиторних ішемічних атак у структурі гострих порушень мозкового кровообігу в Україні та інших країнах. Міжнародний неврологічний журнал. 2017. № 5(91). 
всіх випадків ЦВ3 ${ }^{18,19}$. За даними інших авторів, ХПМК складають $65 \%{ }^{20,21}$. Тобто ЦВ3 є одними 3 найбільш поширених в останні роки та прогресивно зростаючих по частоті розвитку захворювань. Для зміни епідеміологічної ситуації з ЦВЗ в нашій країні необхідне проведення низки заходів щодо виявлення, профілактики та адекватного лікування таких хворих. Для цього необхідно створювати спеціалізовані відділення для лікування і реабілітації, оскільки ранні і обгрунтовані реабілітаційні заходи зменшують ступінь інвалідизації хворих на ЦВ3 $3^{22,23,24}$. Крім того, відновлення особистого i соціального статусу, повернення таким хворим працездатності має велике соціально-економічне значення, а лікування і реабілітація хворих на ЦВЗ і ХІМ - одне з актуальних напрямів в охороні здоров'я ${ }^{25,26}$.

Попри тривалість вивчення цієї проблеми, патогенез цього патологічного стану залишається недостатньо зрозумілим, що стимулює пошук нових патофізіологічних механізмів його розвитку. Особливе значення має вивчення закономірностей формування ЦВЗ різного ступеня тяжкості, оскільки результати

${ }^{18}$ Мищенко Т.С. Эпидемиология цереброваскулярных заболеваний и организация помощи больным с мозговым инсультом в Украине. Украӥнський вісник психоневрологї. 2017. Т. 25(1).

${ }^{19}$ Мищенко Т.С. Анализ состояния распространенности, заболеваемости и смертности от цереброваскулярних заболеваний в Украине. Судинні захворювання головного мозку. 2007. № 3.

20 Зозуля І.С., Зозуля А.І. Епідеміологія цереброваскулярних захворювань в Україні. Український медичний часопис. 2011. № 5(85).

${ }^{21}$ Віничук С.М., Фартушна О.С. Епідеміологія транзиторних ішемічних атак у структурі гострих порушень мозкового кровообігу в Україні та інших країнах. Міжнародний неврологічний журнал. 2017. № 5(91).

22 Зозуля I.C., Зозуля А.І. Епідеміологія цереброваскулярних захворювань в Україні. Украӥнський медичний часопис. 2011. № 5(85). С. 38-41.

${ }^{23}$ Хобзей Н.К., Голик В.А., Гондуленко Н.А., Мищенко Т.С. Особенности эпидемиологии инвалидности при заболеваниях нервной системы в Украине. Міжнародний неврологічний журнал. 2011. № 5(43).

24 Хобзей Н.К., Мищенко Т.С., Голик В.А., Ипатов А.В. Эпидемиология инсульта, клинические и экспертные аспекты в Украине. Судинні захворювання головного мозку. 2010. № 4.

${ }^{25}$ Мищенко Т.С. Эпидемиология цереброваскулярных заболеваний и организация помощи больным с мозговым инсультом в Украине. Український вісник психоневрології. 2017. Т. 25(1).

26 Хобзей Н.К., Голик В.А., Гондуленко Н.А., Мищенко Т.С. Особенности эпидемиологии инвалидности при заболеваниях нервной системы в Украине. Міжнародний неврологічний журнал. 2011. № 5(43). 
такого дослідження дозволять встановити механізми прогресування захворювання і попередити розвиток його тяжких форм. Таким чином, актуальними являються питання вивчення патогенезу, аспектів діагностики, перебігу захворювання, а також визначення можливостей прогнозування його наслідків і можливостей відновлення порушених функцій, підбору оптимальних схем лікування.

Одним 3 аспектів проблеми цереброваскулярної патології $\epsilon$ визначення взаємовідносин між клінічними проявами патологічного процесу та станом адаптаційно-компенсаторних систем організму, до яких відноситься і імунна система. В основу даної розробки покладені результати дослідження останніх років, які стосуються змін окремих імунологічних показників у хворих 3 різними судинними захворюваннями головного мозку $27,28,29,30,31$. Вони можуть свідчити про зміну адаптаційних можливостей організму цих хворих. Відомі також роботи по дослідженню адаптаційних можливостей хворих за даними математичного аналізу ритму серця (РС) ${ }^{32,33}$. Крім того, відомо, що ЦВ3 належать до «хвороб адаптації», основною ознакою яких $є$ порушення пристосувальних реакцій ${ }^{34}$. Ці захворювання пропонується

${ }^{27}$ Крыжановский Г.Н., Магаева С.В. Патология нервной регуляции в генезе иммунных расстройств при заболеваниях центральной нервной системы. Журнал неврологии и психиатрии им. С.С. Корсакова. 1998. № 5.

${ }^{28}$ Шульгинова А.А., Конопля А.И., Быстрова Н.А., Гаврилюк В.П., Караулов А.В. Коррекция иммунных нарушений при хронической ишемии головного мозга. Медицинская иммунология. 2018. Т. 20. № 3.

${ }^{29}$ Шульгинова А.А. Иммунные и метаболические нарушения у больных с хронической ишемией мозга; способы фармакологической дифференцированной коррекции: автореф. дис ... д-ра мед. наук. Москва, 2019.

30 Cruz Y., Cantú-Saldaña K., Ibarra A. Immune System Involvement in the Degeneration, Neuroprotection, and Restoration after Stroke. Open Access books: Ischemic Stroke-Updates. Published: October 19th 2016.

${ }^{31}$ Гусев Е.И., Чуканова А.С. Современные патогенетические аспекты формирования хронической ишемии мозга. Журнал неврологии и психиатрии им. С.С. Корсакова. 2015. № 3.

32 Вейн А.М. (ред.). Вегетативные расстройства: Клиника, диагностика, лечение. Москва : Медицинское информационное агенство, 2003.

${ }^{33}$ Овсянникова К.С. Синдром дезадаптации у пациентов в остром периоде ишемического инсульта: автореф. дис ... канд. мед. наук. Казань, 2018.

${ }^{34}$ Котова О.В., Акарачкова Е.С. Хроническая ишемия головного мозга: патогенетические механизмы и принципы лечения. Фарматека. 2010. № 8. 
розглядати в якості моделі, у клінічній реалізації котрої проявляються взаємовідношення генетичної схильності i адаптаційно-компенсаторних можливостей організму ${ }^{35}$. Тому під час проведення лікування доцільна оцінка адаптаційних можливостей хворих. Проте комплексних робіт, які б оцінювали імунологічні критерії тяжкості захворювання i ix кореляції з результатами дослідження адаптаційних можливостей організму хворих, не проводилось. Проведення таких досліджень дозволить не тільки встановити механізми формування цереброваскулярної патології, але також підвищити ефективність відновного лікування ${ }^{36}$.

Метою роботи було вивчення змін клініко-імунологічних та адаптаційних показників при ЦВЗ різного ступеня тяжкості (XIM I, II, III стадіï), встановити їх значення в прогресуванні ЦВ3.

Згідно з метою і задачами дослідження було обстежено i проліковано 197 хворих з ХІМ різної стадії у віці від 40 до 65 років. 3 них чоловіків - 101, жінок - 96 осіб. 3 ХІМ І ст. було 47, II ст. - 98, III ст. - 52 хворих. Діагноз встановлювався на підставі анамнезу, клінічного аналізу неврологічного статусу та з використанням розробленого математично клінічного індексу тяжкості ${ }^{37}$, нейровізуальних методів дослідження. За походженням XIM в обстеженій групі хворих була змішаного генезу - гіпертонічна та атеросклеротична. Хворих 3 наслідками ГПМК серед досліджуваних пацієнтів не було, але у хворих з III ст. ХІМ відмічались ТПМК та ТІА. В групу порівняння увійшло 20 практично здорових осіб, які обстежувались для встановлення нормативного контролю для імунологічних та адаптаційних показників.

Для оцінки адаптаційних показників використовували математичний аналіз РС, який включав варіаційну пульсометрію,

${ }^{35}$ Гудима Г.О, Ильина Н.И. Новые исследования и новые стратегии современной клинической иммунологии и аллергологии. Иммунология. 2016. Т. 37.

${ }^{36}$ Шульгинова А.А., Конопля А.И., Быстрова Н.А., Гаврилюк В.П., Караулов А.В. Коррекция иммунных нарушений при хронической ишемии головного мозга. Медииинская иммунология. 2018. Т. 20. № 3.

37 Патент України № 71393A, UA, МПК А61N5/06. Спосіб оцінки ступеня тяжкості енцефалопатії. Степаненко І.В., Попова І.Ю., Лихачова Т.А., Бондар Т.С., винахідники. ДУ «нститут нейрохірургії ім. акад. А.П. Ромоданова НАМНУ», патентовласник, опубл. 2004. Бюл. № 11. 
аутокореляційний, спектральний аналізи, статистичні методи ${ }^{38,39,40}$. В будь-якому стандартному відведенні реєструвались 100120 послідовних кардіоінтервалів, які заносились у пам'ять комп'ютера. Математичний аналіз показників РС проводився 3 використанням кібернетичних підходів, для чого була створена відповідна програма.

Імунологічні дослідження I і II порядку проводились 3 визначенням специфічних і неспецифічних показників імунітету, оцінкою стану показників клітинної i гуморальної ланки імунітету. Використовувались методи лазерної проточної цитофлюориметрії з використанням моноклональних антитіл (Т- і В-лімфоцити, субпопуляції Т-лімфоцитів - CD3, CD4, CD8), непрямого імуноферментного аналізу (IФА) (аутоантитіла (аAT) до нейроспецифічних білків - НСБ), дослідження ЦІК, реакції бласттрансформації (РБТЛ) до фітогемаглютинину (ФГА) і в присутності індометацину, тест відновлення НСТ 3 реєстрацією на СФ-16 (фагоцитарна активність нейтрофілів), реакцію 4-годинної цитотоксичності 3 клітинами К-562 хромовим методом (кілерна активність) та інші.

Статистичний аналіз проводився з використанням електронних таблиць Excel-97 i статистичного пакету Statistika 5.0. Для визначення вірогідності відмінностей між кількісними показниками використовувався t-критерій Стьюдента. Для встановлення ступеню і направленості відхилень досліджуваних показників від контрольних значень обчислювали відсоток відхилень за формулою: $\%_{\text {відх }}=\left(\mathrm{A}_{1}-\mathrm{A}_{\mathrm{K}}\right) * 100 \% \div \mathrm{A}_{\mathrm{K}}$, де $\%_{\text {відх }}-\%$ відхилення від контрольних значень (норми); $\mathrm{A}_{1}-$ величина досліджуваного показника; $\mathrm{A}_{\mathrm{K}}$ - середнє значення цього показника в нормі ${ }^{41}$.

\footnotetext{
${ }^{38}$ Баевский Р.М. Вариабельность сердечного ритма: теоретические аспекты и возможности клинического применения. Ультразвуковая $u$ функциональная диагностика. 2001. № 3.

${ }^{39}$ Malik M., Camm A.J. Heart rate variability: standards of measurement, physiological interpretation and clinical use. Task Force of the European 146 Society of Cardiology and the North American Society of Pacing and Electrophysiology. Circulation. 1996. № 93(5).

${ }^{40}$ Бокерия Л.А., Бокерия О.Л., Волковская И.В. Вариабельность сердечного ритма: методы измерения, интерпретация, клиническое использование. Аннальь аритмологии. 2009. Т. 6. № 4.

${ }^{41}$ Минцер О.П, Угаров Б.П., Власов В.В. Методы обработки медицинской информации. Київ : Вища школа. 1991.
} 


\section{1. Динаміка адаптаційних показників за даними математичного аналізу РС при ХІМ різної стадії}

Як відомо, перспективним підходом в оцінці стану організму $\epsilon$ вивчення механізмів гомеостатичного регулювання, які визначають рівень функціонування організму та його систем. 3 цією метою було проведено порівняльне вивчення вираженості порушень неврологічної симптоматики, стану механізмів регуляції РС та імунного статусу у хворих на XIM різної стадії. Такий підхід був обгрунтований тим, що оцінка діяльності механізмів регуляції РС, як і оцінка змін імунних показників, характеризує стан адаптаційних можливостей організму, оскільки таке співставлення зумовлено загальною структурною організацією реакцій, що вивчались. Вивчення основних регуляторних систем - імунної системи та адаптаційних реакцій, було зумовлено також в зв'язку 3 формуванням регуляторної патології у хворих на ЦВЗ. Крім того, на основі комплексного дослідження можуть бути встановлені імунологічні та адаптаційні критерії прогресування захворювання і розроблені схеми відновного лікування. Показники математичного аналізу РС дозволяють виділити стани з різними ступенями активізації симпатичного та парасимпатичного відділів ВНС і отримати інформацію про направленість адаптаційних реакцій. Вивчення імунологічних показників також дає можливість встановити переважання в діяльності єрго- або трофотропних систем, що дозволяє судити про стан адаптаційно-компенсаторних механізмів і за даними імунних показників. Загалом такий підхід дає можливість більш ретельно оцінювати механізми прогресування захворювання і шляхи їх компенсації.

Результати дослідження математичних показників регуляції РС при різних стадіях ХІМ представлені в табл. 1. Вони дозволяють судити про зміни адаптаційних показників при прогресуванні захворювання. Під час інтерпретації адаптаційних показників ми виходили 3 того, що при збільшенні показників централізації (IH, АМо, внесок ПХ ${ }_{2}$, внесок ПХ 1 ) показники варіабельності РС $(\sigma, \mathrm{V}, \Delta \mathrm{X}$, внесок Хдих.) повинні зменшуватись. Їх одночасне збільшення або зменшення свідчить про порушення узгодженості в діяльності центрального і автономного контурів регуляції РС.

Загальний аналіз результатів математичного аналізу РС показав, що в обстеженій групі хворих відмічено зниження активності 
трофотропних (зменшення $\Delta \mathrm{x}, \mathrm{p}<0,01 ; \sigma, \mathrm{p}<0,001)$ i ерготропних (низька $\mathrm{AM}_{\mathrm{o}}, \mathrm{p}<0,01$ ) відділів вегетативної нервової системи з відносним переважанням останніх. Виявлено порушення регуляторних процесів за рахунок централізації управління РС (високий $\mathrm{IH}, \mathrm{p}<0,001$; зниження $\sigma, \mathrm{p}<0,001)$. Відмічено порушення узгодженості в діяльності ерго- і трофотропних відділів вегетативної нервової системи (одночасне зменшення $\Delta \mathrm{x}, \mathrm{M}_{\mathrm{o}}, \mathrm{AM}_{\mathrm{o}}$ ). Дизрегуляція проявлялась також порушенням взаємодії центральних механізмів з автономними (одночасне зниження IH і б). При функціональних пробах (моделювання інтелектуального навантаження та негативних емоцій, ортокліностатична проба) аналізували амплітуду реакції (АР) та час реституції (t). Співставлення даних виявило вірогідне $(\mathrm{p}<0,05)$ зменшення АР i значне $(\mathrm{p}<0,05)$ підвищення $\mathrm{t}$ при всіх пробах. Це свідчило про переважання ерготропних впливів в регуляції вегетативного забезпечення різних функціональних проб. Така перевага $\epsilon$ причиною ослаблення реакції ВНС на зовнішні стимули i зменшення лабільності регуляторних процесів.

При порівняльному аналізі математичних показників регуляції РC у осіб контрольної групи та хворих з легкою (I) стадією XIM (табл. 1), відмічено зниження активності трофотропних структур (зменшення $\Delta \mathrm{X}, \mathrm{p}<0,05 ; \sigma, \mathrm{p}<0,05$; внеску Хдих., $\mathrm{p}<0,05$ ), підвищення активності ерготропних відділів ВНС (збільшення AMo, $\mathrm{p}<0,05$; IBР, $\mathrm{p}<0,05$; ПАПР, $\mathrm{p}<0,05$; ВПР, $\mathrm{p}<0,05$; IH, $\mathrm{p}<0,05 ;$ внеску ПХ $2, \mathrm{p}<0,05$ і внеску ПХ $1, \mathrm{p}<0,05) ; \mathrm{m}_{\mathrm{o}}$ та $\mathrm{m}_{0,3}$ вірогідно збільшились ( $<<0,01$ та $\mathrm{p}<0,05)$.

Відмічені початкові ознаки дизрегуляції - порушення взаємодії центральних ланок управління РС 3 автономними $(\mathrm{V}, \mathrm{p}<0,05)$. Такі зміни свідчать про напруження регуляції РС без суттєвих порушень взаємодії трофотропних (парасимпатичних) та ерготропних (симпатичних) впливів. Рівень функціонування механізмів регуляції РС у хворих 3 I ст. ХІМ став менш досконалим, ніж у здорових (зниження $\mathrm{M}_{\mathrm{o}}, \mathrm{p}<0,05$, підвищення ЧСС, $\mathrm{p}<0,05$ ). АР та $t$ при функціональних пробах не відрізнялись від контрольної групи (табл. 1).

Аналіз математичних показників регуляції РС у хворих 3 II ст. ХІМ виявив зростання активності як автономного, так і центрального контурів регуляції РС (ПАПР, $\mathrm{p}<0,05$; ВПР, $\mathrm{p}<0,05$; $\mathrm{m} 0,3, \mathrm{p}<0,05$; внеску ПХ $\left.{ }_{2}, \mathrm{p}<0,01 ; \Delta \mathrm{X}, \mathrm{p}<0,05\right)$. Одночасне 
підвищення активності ерготропних та трофотропних систем свідчить про розвиток дизрегуляції $(\mathrm{V}, \mathrm{p}<0,05)$, перенапруження діяльності симпатичних та парасимпатичних відділів ВНС. Це означає погіршення рівня функціонування механізмів регуляції РС. При проведенні функціональних проб спостерігалось збільшення $\mathrm{AP}$, при невеликому t: потрібним стало більше напруження механізмів регуляції РС.

Таблиця 1

Математичні показники регуляції РС при різних стадіях ХІМ

\begin{tabular}{|c|c|c|c|c|}
\hline $\begin{array}{c}\text { Матема- } \\
\text { тичні } \\
\text { показники } \\
\text { n =197 }\end{array}$ & $\begin{array}{c}\text { Контрольна } \\
\text { група } \\
\mathbf{M} \pm \mathbf{m} \\
\mathbf{n}=\mathbf{2 0}\end{array}$ & $\begin{array}{c}\text { I ст XIM } \\
\mathbf{M} \pm \mathbf{m} \\
\mathbf{n}=\mathbf{4 7}\end{array}$ & $\begin{array}{c}\text { II ст XIM } \\
\mathbf{M} \pm \mathbf{m} \\
\mathbf{n}=\mathbf{9 8}\end{array}$ & $\begin{array}{c}\text { III ст XIM } \\
\mathbf{M} \pm \mathbf{m} \\
\mathbf{n}=\mathbf{5 2}\end{array}$ \\
\hline$\Delta \mathrm{X}, \mathrm{c}$ & $0,32 \pm 0,04$ & $0,17 \pm 0,01 *$ & $0,44 \pm 0,01 *$ & $0,21 \pm 0,01 *$ \\
\hline$\sigma, \mathrm{c}$ & $0,07 \pm 0,01$ & $0,03 \pm 0,01 *$ & $0,06 \pm 0,01$ & $0,04 \pm 0,01 *$ \\
\hline ЧСС, уд/хв & $65,67 \pm 4,71$ & $71,97 \pm 1,52$ & $65,00 \pm 1,17$ & $65,51 \pm 0,89$ \\
\hline $\mathrm{M}_{\mathrm{o}}, \mathrm{c}$ & $0,93 \pm 0,10$ & $0,85 \pm 0,02 *$ & $0,94 \pm 0,02$ & $0,93 \pm 0,01$ \\
\hline $\mathrm{A} \mathrm{M}_{0}, \%$ & $29,0 \pm 1,00$ & $32,64 \pm 0,28^{*}$ & $28,55 \pm 0,45$ & $26,19 \pm 0,32 *$ \\
\hline IBР, ум.од. & $91,66 \pm 8,33$ & $208 \pm 11,50 *$ & $120,52 \pm 3,60 *$ & $131,72 \pm 4,49 *$ \\
\hline $\begin{array}{l}\text { ПАПР, } \\
\text { ум.од. }\end{array}$ & $31,37 \pm 1,96$ & $38,92 \pm 1,01 *$ & $38,23 \pm 0,87 *$ & $28,47 \pm 0,59 *$ \\
\hline ВПР, ум.од. & $3,49 \pm 0,76$ & $7,63 \pm 0,49 *$ & $4,60 \pm 0,16$ & $2,45 \pm 0,13 *$ \\
\hline IH, ум.од. & $50,19 \pm 9,34$ & $125,93 \pm 9,10 * *$ & $65,73 \pm 2,56$ & $71,94 \pm 2,88 *$ \\
\hline $\begin{array}{l}\text { внесок } \\
\Pi X_{2}, \% \\
\end{array}$ & $12,11 \pm 12,83$ & $46,11 \pm 3,78^{*}$ & $41,31 \pm 3,44 * *$ & $41,64 \pm 2,47 *$ \\
\hline $\begin{array}{l}\text { внесок } \\
\Pi X_{1}, \%\end{array}$ & $12,07 \pm 3,35$ & $16,49 \pm 1,59^{*}$ & $12,96 \pm 1,27$ & $13,79 \pm 0,86$ \\
\hline $\begin{array}{l}\text { внесок } \\
\text { Хдих,\% }\end{array}$ & $43,02 \pm 3,23$ & $23,38 \pm 2,24^{*}$ & $26,04 \pm 1,75$ & $26,37 \pm 1,38 *$ \\
\hline $\mathrm{m}_{\mathrm{o}}$ & $1,20 \pm 1,10$ & $32,15 \pm 2,81 * *$ & $11,67 \pm 1,58$ & $28,77 \pm 2,20$ \\
\hline $\mathrm{m}_{0,3}$ & $1,50 \pm 0,50$ & $32,15 \pm 2,81^{*}$ & $27,57 \pm 2,71 *$ & $7,40 \pm 0,86$ \\
\hline $\mathrm{V}, \%$ & $7,92 \pm 0,07$ & $3,82 \pm 0,10 *$ & $4,89 \pm 0,10 *$ & $4,39 \pm 0,09 *$ \\
\hline
\end{tabular}

Примітка: * $-p<0,05$ по відноменню до контрольних значень; $* *-P<0,01$.

Аналіз математичних показників РС у пацієнтів 3 III ст. XIM свідчить про зниження активності трофотропних систем порівняно 3 особами контрольної групи $(\Delta \mathrm{X}, \mathrm{p}<0,05 ; \sigma, \mathrm{p}<0,05$; внесок Хдих., 
$\mathrm{p}<0,05)$ з одночасним зниженням активності i ерготропних систем - зменшення ПАПР ( $<<0,05)$; ВПР (p < 0,05) при збільшенні внеску ПХ ${ }_{2}(\mathrm{p}<0,05)$. При цьому рівень порушень частини показників був більшим при II ст. ХІМ. Зазначені зміни свідчать про значні порушення взаємодії елементів центрального та автономного контурів регуляції РС, а також про дизрегуляцію між ерготропними та трофотропними впливами, паралельне зниження їх активності. Таку динаміку показників можна розцінювати як виснаження адаптаційних можливостей. При функціональних пробах спостерігалась ареактивність регуляції РС - невелика АР та значний $\mathrm{t}$, що свідчить про значне зниження лабільності нервових процесів.

\section{2. Динаміка імунологічних показників при ХІМ різної стадії}

Аналіз стану імунної системи у хворих з різною стадією ХІМ (табл. 2) проводився за даними динаміки показників клітинного і гуморального імунітету (Т- і В-лф і їх кооперації, Т-хелперів Т-супресорів, IPI, ЦІК, аАТ до НСБ - ОБМ, NSE, S-100, фагоцитозу та ін.), оскільки вони свідчать про стан гіпоталамічних відділів головного мозку як центрального імунорегуляторного апарату та відображають активність симпатичної або парасимпатичної ланки ВНС. Аналіз результатів імунологічного обстеження хворих був побудований на виявленні ступеню відхилень вивчених показників імунного статусу в залежності від їх напряму, оскільки напрям зрушень імунологічних показників має принципове значення в оцінці імунного статусу та механізмів його порушення.

Загальний аналіз змін імунного статусу встановив, що у більшості хворих відбуваються як кількісні, так і функціональні зміни Т- і В- клітинної ланки імунітету і природних кілерних клітин (ПКК). Більш детальний аналіз ступеню відхилень показав, що серед вивчених середніх значень показників відмічались як незначні, так і виражені зрушення. Так, на рівні близькому до контрольних залишались абсолютні значення лімфоцитів i Т-лімфоцитів, $\mathrm{CD}_{8}$-лімфоцити, супресорна активність (Інд/ФГА). Помірні відхилення спостерігались в рівні лейкоцитозу i лімфоцитозу $(+12,3 \%$ і +13\%), співвідношенні Т/В (+15,1\%), $\mathrm{CD}_{3}$-лімфоцитів $(-14,4 \%), \mathrm{CD}_{4}$-хелперів $(-15,7 \%)$, імунорегуляторного індексу $\left(\mathrm{CD}_{4} / \mathrm{CD}_{8}\right)(-15 \%)$, аАТ до НСБ - ОБМ $(+14,04 \%)$ i S100 (+15\%), значеннях РБТЛ у відповідь на ФГА (-14,9\%). Значні 
зрушення спостерігались в рівні аАT до NSE (+96,7\%), спонтанної проліферативної активності (+126\%) і активності природних кілерних клітин ПКК (-56,4\%). Зміни інших показників були в межах 20\%-31\%. Виявлені зрушення поглиблювались при зростанні тяжкості захворювання і залежали від особливостей функціонування супрасегментарних вегетативних центрів (сипатотонія, ваготонія). Тобто представлені дані виявили різноспрямовані зміни вивчених показників. При цьому середні значення більшості показників були помірно відхилені від контрольних, однак виявлялись у значної кількості хворих. Загальний аналіз отриманих даних показав також, що частота $\mathrm{i}$ вираженість функціональних змін дещо переважала над кількісними. Серед останніх частота клітинних і гуморальних порушень була майже однакова. При цьому в зрушеннях клітинних параметрів імунітету переважали від'ємні, а гуморальних - позитивні відхилення від контрольних значень, що може свідчити про порушення кооперативних зв'язків між клітинами, тобто ілюструє дисфункціональні і дизрегуляторні порушення імунного статусу. Отримані дані свідчать також про формування у таких хворих різних типів імунодефіциту, 3 переважанням у частини хворих аутоімунних реакцій, а у інших - порушень протиінфекційного і протионкологічного захисту, які підтримувались порушеними нейроімунорегуляторними впливами.

При аналізі змін імунного статусу залежно від стадії ХIM (табл.2) було встановлено, що при I ст. XIM відмічалось незначне зниження (не більше 10-12\%) кількісних показників імунітету - Т- i B-лф, IPI, аАТ до ОБМ, і таке ж незначне підвищення Т/B, CD8, aAT до S-100 i NSE при нормальних значеннях CD4 і ЦІК. Показники функціональної активності імунної системи - фагоцитарний індекс, індукована проліферація лімфоцитів в тесті з фітогемаглютинином (ФГА) і супресорна активність моноцитів в тесті 3 індометацином (ФГА + Інд), а також частково i їх співвідношення (Інд/ФГА) були переважно знижені - до 15-19\%. Тобто спостерігались незначні зміни переважно функціональної активності імунокомпетентних клітин. Це узгоджувалось 3 показниками математичного аналізу РС - при I ст. відмічались початкові ознаки дизрегуляції без суттєвих порушень трофотропних та ерготропних впливів (табл. 2). 


\section{Середні значення імунологічних показників} при різних стадіях XIM

\begin{tabular}{|c|c|c|c|c|}
\hline $\begin{array}{c}\text { Імунологічні } \\
\text { показники } \\
\mathbf{n}=197\end{array}$ & $\begin{array}{c}\text { Контрольна } \\
\text { група } \\
\mathbf{M} \pm \mathbf{m} \\
\mathbf{n}=\mathbf{2 0}\end{array}$ & $\begin{array}{c}\text { I ст XIM } \\
M \pm \mathbf{m} \\
\mathrm{n}=\mathbf{4 7}\end{array}$ & $\begin{array}{c}\text { II ст XIM } \\
\mathbf{M} \pm \mathbf{m} \\
\mathbf{n}=\mathbf{9 8}\end{array}$ & $\begin{array}{c}\text { III ст XIM } \\
\quad \begin{array}{l}\text { M } \pm \mathbf{m} \\
\mathbf{n}=\mathbf{5 2}\end{array}\end{array}$ \\
\hline $\begin{array}{l}\text { Т-лф } \\
\text { \% відхилення }\end{array}$ & $65,2 \pm 1,4$ & $\begin{array}{c}57,0 \pm 2,15^{*} \\
-12,6\end{array}$ & $\begin{array}{c}52,8 \pm 1,48^{*} \\
-19\end{array}$ & $\begin{array}{c}50,8 \pm 1,78^{*} \\
-22,1\end{array}$ \\
\hline $\begin{array}{l}\text { В-лф } \\
\text { \% відхилення }\end{array}$ & $15,2 \pm 0,8$ & $\begin{array}{c}13,0 \pm 0,89^{*} \\
-14,5\end{array}$ & $\begin{array}{c}12,3 \pm 1,07^{*} \\
-19\end{array}$ & $\begin{array}{c}11,9 \pm 1,01^{*} \\
-21,7\end{array}$ \\
\hline $\begin{array}{l}\mathrm{T} \backslash \mathrm{B} \\
\text { \% відхилення }\end{array}$ & $4,3 \pm 0,5$ & $\begin{array}{c}5,1 \pm 0,21 \\
+18,6\end{array}$ & $\begin{array}{c}4,9 \pm 0,19 \\
+14\end{array}$ & $\begin{array}{c}4,7 \pm 0,23 \\
-21,7\end{array}$ \\
\hline $\begin{array}{l}\text { CD4 } \\
\text { \% відхилення }\end{array}$ & $45,8 \pm 2,7$ & $\begin{array}{c}45,0 \pm 3,12 \\
-1,7\end{array}$ & $\begin{array}{c}37,0 \pm 3,79 \\
-19,2\end{array}$ & $\begin{array}{c}35,5 \pm 2,51^{*} \\
-22,5\end{array}$ \\
\hline $\begin{array}{l}\text { CD8 } \\
\text { \% відхилення }\end{array}$ & $32,0 \pm 2,7$ & $\begin{array}{l}35,85 \pm 4,16 \\
\quad+12,03\end{array}$ & $\begin{array}{c}30,9 \pm 2,12 \\
-3,4\end{array}$ & $\begin{array}{c}37,5 \pm 2,51 \\
-17,2\end{array}$ \\
\hline $\begin{array}{l}\text { CD4 \CD8 } \\
\text { \% відхилення }\end{array}$ & $1,4 \pm 0,08$ & $\begin{array}{c}1,23 \pm 0,05 \\
-12,1\end{array}$ & $\begin{array}{c}1,24 \pm 0,041 \\
-11,4\end{array}$ & $\begin{array}{c}1,2 \pm 0,06^{*} \\
-14,3\end{array}$ \\
\hline $\begin{array}{l}\mathrm{A} \backslash \text { ат до ОБМ } \\
\text { \% відхилення }\end{array}$ & $11,4 \pm 2,5$ & $\begin{array}{c}9,8 \pm 1,64 \\
-14\end{array}$ & $\begin{array}{c}12,1 \pm 1,74 \\
+6,1\end{array}$ & $\begin{array}{c}14,1 \pm 1,23 \\
+23,7\end{array}$ \\
\hline 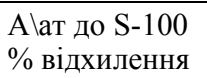 & $2,0 \pm 0,2$ & $\begin{array}{c}2,2 \pm 0,52 \\
+10\end{array}$ & $\begin{array}{c}2,3 \pm 0,28 \\
+15\end{array}$ & $\begin{array}{l}2,5 \pm 0,41^{*} \\
+25\end{array}$ \\
\hline 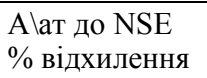 & $2,4 \pm 0,4$ & $\begin{array}{l}2,72 \pm 0,62 \\
+13,3\end{array}$ & $\begin{array}{c}3,93 \pm 0,70^{* *} \\
+63\end{array}$ & $\begin{array}{c}6,81 \pm 1,17 * * \\
+183,8\end{array}$ \\
\hline $\begin{array}{l}\text { ЦІК } \\
\text { \% відхилення }\end{array}$ & $95 \pm 10,1$ & $\begin{array}{c}91,0 \pm 11,8 \\
-4,2\end{array}$ & $\begin{array}{c}138,2 \pm 16,4^{* *} \\
+58\end{array}$ & $\begin{array}{c}108,7 \pm 12,75 \\
+14,4\end{array}$ \\
\hline $\begin{array}{l}\text { ФАГиндекс } \\
\text { \% відхилення }\end{array}$ & $37,6 \pm 4,4$ & $\begin{array}{c}31,3 \pm 4,91 \\
-16,8\end{array}$ & $\begin{array}{c}31,0 \pm 3,10 \\
-17,6\end{array}$ & $\begin{array}{c}15,0 \pm 1,76^{*} \\
-60,1\end{array}$ \\
\hline $\begin{array}{l}\text { ФАГ число } \\
\text { \% відхилення }\end{array}$ & $4,1 \pm 0,39$ & $\begin{array}{c}3,9 \pm 0,53 \\
-4,9\end{array}$ & $\begin{array}{c}6,3 \pm 0,67^{* *} \\
+53,7\end{array}$ & $\begin{array}{c}3,9 \pm 0,29 \\
-4,9\end{array}$ \\
\hline $\begin{array}{l}\text { ФГА } \\
\text { \% відхилення }\end{array}$ & $61,0 \pm 2,30$ & $\begin{array}{c}52,44 \pm 2,28^{*} \\
-14,0\end{array}$ & $\begin{array}{c}49,19 \pm 1,94^{*} \\
-19,4\end{array}$ & $\begin{array}{c}48,39 \pm 2,87^{*} \\
-20,7\end{array}$ \\
\hline $\begin{array}{l}\text { Інд } \\
\text { \% відхилення }\end{array}$ & $75 \pm 0,2$ & $\begin{array}{c}60,4 \pm 3,57^{*} \\
-19,5\end{array}$ & $\begin{array}{c}57,8 \pm 6,40^{*} \\
-22,9\end{array}$ & $\begin{array}{c}54,4 \pm 3,40^{*} \\
-27,5\end{array}$ \\
\hline 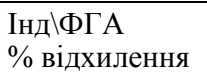 & $1,23 \pm 0,07$ & $\begin{array}{c}1,16 \pm 0,06 \\
-5,7\end{array}$ & $\begin{array}{c}1,14 \pm 0,08 \\
-7,3\end{array}$ & $\begin{array}{c}1,15 \pm 0,09 \\
-6,8\end{array}$ \\
\hline $\begin{array}{l}\text { К } \\
\text { \% відхилення }\end{array}$ & 0 & $\begin{array}{c}1,14 \pm 0,29^{* *} \\
+114\end{array}$ & $\begin{array}{l}1,12 \pm 0,30^{* *} \\
+112\end{array}$ & $\begin{array}{c}1,76 \pm 1,04^{* *} \\
+176\end{array}$ \\
\hline
\end{tabular}

Примітка: ${ }^{*}-p<0,05$ по відноменню до контрольних значень; ** $-P<0,01$. 
Кількісні i функціональні порушення імунокомпетентних клітин при II ст. поглиблювались - зрушення показників відмічалось до $20-60 \%$, особливо вірогідно $(\mathrm{p}<0,05)$ зростав рівень aАТ до всіх НСБ (ОБМ, S-100 і, особливо, NSE), ЦІК, на фоні вірогідно зниженого рівня Т- і В- лімфоцитів, імунорегуляторних лімфоцитів та IPI, та зниження фагоцитарного індексу 3 одночасним підвищенням фагоцитарного числа (ознаки незавершеності реакції), зниження супресорної і індукованої проліферативної активності, підвищення спонтанної проліферації. Тобто спостерігалось зростання змін імунних показників, особливо гуморального імунітету, які свідчили про напруження в діяльності ерготропної системи на фоні суттєвого зниження функціональної активності імунокомпетентних клітин. Це співпадало зі змінами показників РC, які свідчили про розвиток дизрегуляції, перенапруження діяльності симпатичних та парасимпатичних відділів ВНС.

При аналізі імунного статусу при III ст. ХІМ спостерігалось подальше поглиблення змін його показників, однак окремі 3 них були змінені в меншій мірі, або такі ж, як і при II ст. Передусім це підвищені значення ЦІК (за частотою і рівнем), аАТ до ОБМ і S-100 (за частотою), знижені значення Тс (за частотою), знижені i підвищені значення імунорегуляторного індексу - Тх/Тc (за рівнем), підвищені рівні Т- і В-лф та співвідношення Т/B, знижена фагоцитарна активність (за частотою і рівнем), що вказувало на виснаження гуморальних імунних реакцій при значному зниженні функціональної активності імунокомпетентних клітин при III ст. XIM і відображало суттєве зниження активності і ерготропної, і трофотропної систем, їх виснаження та зниження захисних властивостей організму. Одночасно спостерігалось виснаження і адаптаційних реакцій.

Виявлені зміни імунного статусу свідчать про суттєве зниження імунорегуляторних механізмів, адаптаційно-компенсаторних i резервних можливостей імунної системи і вказують на імунопатологічний тип реагування і зростаючу декомпенсацію імунної системи, які можуть бути зумовлені недостатністю функціонування гіпоталамічних відділів головного мозку. Тобто при зростанні тяжкості захворювання суттєво знижуються адаптаційно-компенсаторні можливості хворих за рахунок порушення діяльності супрасегментарних вегетативних механізмів, що підтверджується 
результатами дослідження як адаптаційних, так i імунологічних показників. Виявлені зміни стосуються головним чином механізмів регуляції. Отримані дані свідчать також про те, що в розвитку ЦВЗ, i XIM зокрема, значне місце належить аутоімунним процесам 3 утворенням аАТ до всіх вивчених НСБ, особливо до нейрональних структур (NSE), які створюють передумови до прогресування захворювання, що підтримується також суттєвим зниженням функціональної активності імунної системи. Виявлені зрушення в рівнях вивчених адаптаційних і імунологічних показників при II ст. XIM підтверджують наявність перенапруження в механізмах формування адаптаційно-компенсаторних реакцій i вказують на можливість їх виснаження і зриву, що повинно давати підстави для активного впливу на процеси компенсації виявлених змін вже при II ст. XIM з метою попередження прогресування захворювання.

\section{3. Обговорення результатів дослідження}

Відомо, що адаптація включає два основних процеси: мобілізацію функціональних резервів у відповідь на дію стресора і відновлення резервних можливостей для адекватної реакції на стрес. Мобілізацію забезпечують ерготропні механізми, діяльність яких проявляється активацією симпатичного відділу ВНС. Така реакція характеризується напруженням процесів регуляції, централізацією управління РС, слабкістю автономного контуру. Одночасно спостерігається активація гуморальної ланки імунної системи 3 підвищенням аутоімунних i імунокомплексних реакцій на фоні зниження клітинного імунітету та загального зниження функціональної активності імунної системи, що також свідчить про напруження в діяльності імунної системи. Співдружня взаємодія всіх елементів системи забезпечує максимальні адаптаційні можливості. Порушення взаємодії центрального i автономного контура управління РС, діяльності симпатичної та парасимпатичної систем являється ознакою дезадаптації i дизрегуляції. Подальше прогресування захворювання супроводжується включенням в процес трофотропних механізмів та їх поступовим виснаженням на фоні прогресуючого зниження функціональної активності імунокомпетентних клітин з відповідним зниженням адаптаційних можливостей організму. Все це відображає стан систем лімбіко-ретикулярного комплексу (ЛРК), передусім гіпоталамічних структур, рівень функціонування яких суттєво знижується внаслідок порушення церебральної гемодинаміки 
при XIM, зумовленої погіршенням стану чутливих до гіпоксії систем ЛРК внаслідок їх входження в зону суміжного кровопостачання двох основних артеріальних басейнів - каротидного та вертебробазилярного ${ }^{42}$. Пошкодження ГЕБ ${ }^{43,44,45,46}$ при цереброваскулярних захворюваннях призводить до активного перебігу гуморальних імунних реакцій 3 подальшою їх імуномодуляцією та прогресуванням деструктивних процесів в нервовій тканині ${ }^{47,48,49,50,51}$. Це підтверджується зростанням рівня аутоантитіл до НСБ, в найбільшій мірі - до нейрональних структур (NSE) та іншими порушеннями імунного статусу, а також даними нейровізуалізуючих досліджень, які виявили ознаки зростаючого пошкодження мозкової тканини саме в цих ділянках мозку.

Виявлені зміни імунного статусу $\mathrm{i}$ адаптаційних реакцій у хворих на ЦВЗ свідчать про суттєве зниження імунорегуляторних механізмів, адаптаційно-компенсаторних і резервних можливостей

${ }^{42}$ Ельчанинов А.П., Кузнецов С.В. Влияние фраксипарина на томографические показатели церебральной перфузии при дисциркуляторной энцефалопатии у молодых лиц. Журнал неврологии и психиатрии им. С.С. Корсакова. 2008. Вып. 22: Инсульт, приложение к журналу.

43 Бережанская С.Б., Лукьянова Е.А., Жаворонкова Т.Э. и др. Современная концепция структурно-функциональной организации гематоэцефалического барьера и основные механизмы нарушения его резистентности. Педиатрия. Журнал им. Г.Н. Сперанского. 2017. Т. 96. № 1.

${ }^{44}$ Герасимова М.M. Роль аутоиммунного процесса в патогенезе геморрагического инсульта. Журнал неврологии и психиатрии им. С.С. Корсакова. 2003. № 8: Инсульт, приложение к журналу.

${ }^{45}$ Крыжановский Г.И., Магаева С.В., Макаров С.Д. Нейроиммунопатология. Москва, 1997.

${ }^{46}$ Березин В.А., Белик Я.В. Специфические белки нервной ткани. Киев: Наукова думка, 1990.

${ }^{47}$ Крыжановский Г.И., Магаева С.В., Макаров С.Д. Нейроиммунопатология. Москва, 1997.

${ }^{48}$ Скворцова В.И. Механизмы повреждающего действия церебральной ишемии и нейропротекция. Вестник РАМН. 2003. № 11.

${ }^{49}$ Stadnik S.M., Saiko O.V., Hayda I.V. Immunological aspects in the acute period of ischemic stroke. Міжнародний неврологічний журнал. 2020. Т. 16. № 5.

${ }^{50}$ Кашаева Л.Н., Карзакова Л.М., Саперов В.Н. Иммунологические нарушения при церебральных инсультах и их коррекция. Медицинская иммунология. 2005. Т. 7. № 1 .

${ }^{51}$ Королева Е.С., Бразовская Н.Г., Левчук Л.А. и др. Оценка уровней нейронспецифической енолазы и мозгового нейротрофического фактора на этапах реабилитации в остром и раннем восстановительном периодах ишемического инсульта. Журнал неврологии и психиатрии им. С. С. Корсакова. Спецвыпуски. 2020. T. 120. 
імунної системи і організму загалом, які можуть бути зумовлені недостатністю функціонування гіпоталамічних відділів головного мозку. Ці зміни мають особливе значення при визначенні програм відновного лікування, які повинні включати заходи по підвищенню компенсаторно-адаптаційних можливостей вже при II ст. захворювання, але особливо при III ст. Порівняння показників математичного аналізу РС 3 результатами психологічних тестів, імунними показниками, індексом активності дозволять в кожному конкретному випадку отримати уяву про протікання процесу адаптації з метою корекції реабілітаційних програм та прогнозування результатів відновного лікування.

Таким чином, проведене комплексне клінічне обстеження хворих, a також дослідження імунологічного статусу та адаптаційних показників за даними математичного аналізу РC, дозволило встановити, що у пацієнтів з ХІМ, незалежно від тяжкості захворювання, виявляються структурні порушення мозкової тканини i перфузії головного мозку, переважно в гіпоталамічних ділянках, які супроводжуються порушенням діяльності центральних регуляторних механізмів, в тому числі і нейроімунорегуляторних, та значним зниженням адаптаційно-компенсаторних можливостей організму. Виявлені зрушення передують клінічним проявам захворювання i зростають при зростанні тяжкості захворювання. Тому вони мають велике прогностичне значення, оскільки дозволяють встановити групи ризику розвитку і прогресування тяжких форм захворювання та своєчасно проводити відповідне відновне лікування.

Критерієм прогресування захворювання можуть бути зміни показників, що свідчать про зниження активності і дизрегуляцію в діяльності ерготропних і трофотропних систем - зменшення $\Delta \mathrm{X}$, $\sigma$, внеску Хдих., ПХ 2 , ПАПР, ВПР, а також підвищення ЦІК і аАТ до всіх НСБ - ОБМ, S-100 i, особливо, NSE, зниження рівня основних класів лімфоцитів i імунорегуляторних лімфоцитів та зниження показників функціональної активності імунної системи.

Проведені дослідження дозволили виявити найбільш інформативні показники для оцінки реабілітаційного потенціалу, що дозволило сформулювати принципи індивідуалізації відновного лікування хворих на XIM для підвищення його ефективності у кожного хворого. Застосовані в зв'язку з отриманими даними патогенетично обгрунтовані медикаментозні і немедикаментозні методи лікування підвищували адаптаційно-компенсаторні можливості організму i 
оптимізовували його резервні можливості, що призводило до підвищення темпів функціонального відновлення. Виявлена позитивна динаміка адаптаційних і імунологічних показників внаслідок лікування підтвердила, що під його впливом відбувається включення основних життєво важливих систем організму в складний комплекс компенсаторних реакцій, спрямованих на підтримку гомеостазу, що супроводжувалось покращенням інтегративних i регуляторних функцій головного мозку за рахунок впливу на гіпоталамічні відділи головного мозку з послабленням симпатикотонічних і посиленням трофотропних регуляторних впливів.

Підводячи підсумки усіх проведених при виконанні даної роботи досліджень були зроблені наступні висновки.

\section{ВИСНОВКИ}

1. Проведене комплексне дослідження встановило, що у хворих на ЦВЗ розвивається симптоматика дифузного ураження головного мозку органічного характеру - XIM, з ознаками ураження всіх його рівнів - кори, підкіркових утворень і стовбура мозку, особливо гіпоталамуса, що супроводжується розвитком синдрому дезадаптації і дезінтеграції, які поглиблюються при зростанні тяжкості захворювання.

2. Дослідження адаптаційних показників методом математичного аналізу РС встановило дизрегуляцію в діяльності центрального і автономного контуру (ерго- та трофотропних структур), особливості порушень адаптаційно-компенсаторних механізмів при різних стадіях XIM та найбільш інформативні показники для оцінки реабілітаційного потенціалу.

3. Дослідження імунного статусу виявило нейроімунорегуляторні порушення зі зниженням адаптаційно-компенсаторних можливостей і неспецифічної резистентності, формуванням різних типів імунодефіциту, які обтяжують перебіг захворювання, зростають при зростанні тяжкості захворювання i залежать від особливостей функціонування ВНС і клінічного перебігу захворювання.

4. Дизрегуляція в діяльності центрального і автономного контуру регуляції РС, зниження активності ерго- і трофотропних систем, а також підвищення активності гуморальної ланки імунної системи на фоні зниження рівня основних класів лімфоцитів і імунорегуляторних лімфоцитів та зниження показників функціональної активності імунної системи може служити прогностичним критерієм 
прогресування захворювання і свідчить про необхідність проведення активного відновного лікування вже при II стадії захворювання.

\section{АНОТАЦІЯ}

Вивчено динаміку клініко-імунологічних та адаптаційних показників (за даними математичного аналізу РС) при ХIM різного ступеня тяжкості. Встановлено, що при ХІМ розвивається симптоматика дифузного ураження головного мозку, переважно його гіпоталамічних відділів, що проявляється синдромом дезадаптації та дезінтеграції і свідчить про розвиток регуляторної патології. Проведене дослідження встановило, що зміни імунологічних показників та показників РС, що характеризують ці синдроми, чітко корелюють між собою. Доведено, що основними прогностичними критеріями розвитку тяжких форм захворювання $\epsilon$ ступінь дизрегуляції в діяльності центрального i автономного контурів регуляції РС: одночасне зниження активності ерго- i трофотропних систем. При цьому спостерігається підвищення активності гуморальної ланки імунної системи на фоні зниження функціональної активності імунокомпетентних клітин і рівня основних класів лімфоцитів та імунорегуляторних лімфоцитів. Ці показники є критеріями прогресування ЦВЗ, врахування яких буде сприяти підбору адекватних, індивідуальних схем лікування.

\section{ЛІТЕРАТУРА}

1. Мищенко Т.С. Эпидемиология цереброваскулярных заболеваний и организация помощи больным с мозговым инсультом в Украине. Український вісник психоневрології. 2017. Т. 25(1). C. 22-24. URL: http://nbuv.gov.ua/UJRN/Uvp_2017_25_1_5.

2. Currie C., Morgan C., Gill L., et al. Epidemiology and costs of acute hospital care for cerebrovascular disease in diabetic and nondiabetic populations. Stroke. 1997. V. 28, № 6. P. 1142-1146. DOI: 10.1161/ 01.str.28.6.1142. PMID: 9183340.

3. Зозуля І.С., Зозуля А.І. Епідеміологія цереброваскулярних захворювань в Україні. Украӥнський медичний часопис. 2011. № 5(85), C. 38-41. URL: http://nbuv.gov.ua/UJRN/UMCh_2011_5_13.

4. Vemmos K., Bots M., Tsibouris P., et al. Stroke incidence and fatality in Southern Grecce. Stroke. 1999. V. 30, № 2, P. 363-370. DOI:10.1161/01.STR.30.2.363. 
5. Регіональні особливості рівня здоров'я народу України: аналітично-статистичний посібник. Київ, 2013. 165 с.

6. Мищенко Т.С. Анализ состояния распространенности, заболеваемости и смертности от цереброваскулярних заболеваний в Украине. Судинні захворювання головного мозку. 2007. № 3. С. 2-4.

7. Гусев Е.И., Боголепова А.Н. Депрессивные расстройства у больных, перенесших инсульт. Журнал неврологии и психиатрии им. С.С. Корсакова. 2008. Вып. 22: Инсульт, приложение к журналу. С. 10-15.

8. Віничук С.М., Фартушна О.С. Епідеміологія транзиторних ішемічних атак у структурі гострих порушень мозкового кровообігу в Україні та інших країнах. Міжнародний неврологічний журнал. 2017. № 5(91). C. 105-111. DOI: 10.22141/2224-0713.5.91.2017. 110863.

9. Хобзей Н.К., Голик В.А., Гондуленко Н.А., Мищенко Т.С. Особенности эпидемиологии инвалидности при заболеваниях нервной системы в Украине. Міжнародний неврологічний журнал. 2011. № 5(43). С. 13-16. Режим доступу: http://www.mif-ua.com/ archive/article/21505.

10. Калашников Н.В., Кузнецова С.М., Ена Л.М., и др. Анализ эпидемиологической ситуации с церебральной сосудистой патологией и некоторыми другими болезнями системы кровообращения, сложившейся в Украине в 1980-2001гг. Журнал АМН України. 2004. № 4. С.716-736.

11. Хобзей Н.К., Мищенко Т.С., Голик В.А., Ипатов А.В. Эпидемиология инсульта, клинические и экспертные аспекты в Украине. Судинні захворювання головного мозку. 2010. № 4. C. $2-5$.

12. Крыжановский Г.Н., Магаева С.В. Патология нервной регуляции в генезе иммунных расстройств при заболеваниях центральной нервной системы. Журнал неврологии и психиатрии им. С.С. Корсакова. 1998. № 5. С. 60-64.

13. Шульгинова А.А., Конопля А.И., Быстрова Н.А., Гаврилюк В.П., Караулов А.В. Коррекция иммунных нарушений при хронической ишемии головного мозга. Медищинская иммунология. 2018. Т. 20. № 3. С. 401-410. DOI: 10.15789/1563-0625-20183-401-410.

14. Шульгинова А.А. Иммунные и метаболические нарушения у больных с хронической ишемией мозга; способы фармакологи- 
ческой дифференцированной коррекции : автореф. дис ... д-ра мед. наук. Москва, 2019, 46c. URL: https://www.dissercat.com/content/ immunnye-i-metabolicheskie-narusheniya-u-bolnykh-s-khronicheskoiishemiei-mozga-sposoby-farm.

15. Cruz Y., Cantú-Saldaña K., Ibarra A. Immune System Involvement in the Degeneration, Neuroprotection, and Restoration after Stroke. Open Access books: Ischemic Stroke-Updates. Published: October 19th 2016. DOI: $10.5772 / 64318$.

16. Гусев Е.И., Чуканова А.С. Современные патогенетические аспекты формирования хронической ишемии мозга. Журнал неврологии и психиатрии им. С.С. Корсакова. 2015. № 3. С. 4-8. DOI: 10.17116/jnevro2015115314-8.

17. Вейн А.М. (ред.). Вегетативные расстройства: Клиника, диагностика, лечение. Москва: Медицинское информационное агенство, 2003. 749 с. Режим доступу: https://www.booksmed.com/ nevrologiya/77-vegetativnye-rasstrojstva-vejn klinika.html.

18. Овсянникова К. С. Синдром дезадаптации у пациентов в остром периоде ишемического инсульта : автореф. дис ... канд. мед. наук. Казань, 2018. 23 с. URL: https://www.dissercat.com/content/ sindrom-dezadaptatsii-u-patsientov-v-ostrom-periode-ishemicheskogoinsulta.

19. Котова О.В., Акарачкова Е.С. Хроническая ишемия головного мозга: патогенетические механизмы и принципы лечения. Фарматека. 2010. № 8. С. 57-61. URL: https://pharmateca.ru/ru/archive/ article/7823.

20. Гудима Г.О, Ильина Н.И. Новые исследования и новые стратегии современной клинической иммунологии и аллергологии. Иммунология. 2016. Т. 37. № 2, С. 134-136. DOI: 10.18821/02064952-2016-37-2-134-136.

21. Патент України № 71393A, UA, МПК А61N5/06. Спосіб оцінки ступеня тяжкості енцефалопатії. Степаненко І.В., Попова I.Ю., Лихачова Т.А., Бондар Т.С., винахідники. ДУ «Інститут нейронхірургії ім. акад. А.П. Ромоданова НАМНУ», патентовласник, опубл. 2004. Бюл. № 11.

22. Баевский P.М. Вариабельность сердечного ритма: теоретические аспекты и возможности клинического применения. Ультразвуковая и функииональная диагностика. 2001. № 3. C. $106-127$. 
23. Malik M., Camm A.J. Heart rate variability: standards of measurement, physiological interpretation and clinical use. Task Force of the European 146 Society of Cardiology and the North American Society of Pacing and Electrophysiology. Circulation. 1996. № 93(5). P. 1043-1065. PMID: 8598068.

24. Бокерия Л.А., Бокерия О.Л., Волковская И.В. Вариабельность сердечного ритма: методы измерения, интерпретация, клиническое использование. Анналь аритмологии. 2009. Т. 6. № 4. C. 21-32. Режим доступу: https://cyberleninka.ru/article/n/variabelnostserdechnogo-ritma-metody-izmereniya-interpretatsiya-klinicheskoeispolzovanie/viewer.

25. Минцер О.П, Угаров Б.П., Власов В.В. Методы обработки медицинской информации. Київ : Вища школа. 1991. 271 с.

26. Ельчанинов А.П., Кузнецов С.В. Влияние фраксипарина на томографические показатели церебральной перфузии при дисциркуляторной энцефалопатии у молодых лиц. Журнал неврологии и психиатрии им. С.С. Корсакова. 2008. Вып. 22: Инсульт, приложение к журналу. С. 39-42.

27. Бережанская С.Б., Лукьянова Е.А., Жаворонкова Т.Э. и др. Современная концепция структурно-функциональной организации гематоэцефалического барьера и основные механизмы нарушения его резистентности. Педиатрия. Журнал им. Г.Н. Сперанского. 2017. T. 96. № 1. C. 135-141. URL: https://pediatriajournal.ru/ archive? show $=356 \&$ section $=4832$.

28. Герасимова М.М. Роль аутоиммунного процесса в патогенезе геморрагического инсульта. Журнал неврологии и психиатрии им. С.С. Корсакова. 2003. № 8: Инсульт, приложение к журналу. C. $48-52$.

29. Крыжановский Г.И., Магаева С.В., Макаров С.Д. Нейроиммунопатология. Москва,1997. 282 с.

30. Березин В.А., Белик Я.В. Специфические белки нервной ткани. Киев : Наукова думка, 1990. 263 с.

31. Скворцова В.И. Механизмы повреждающего действия церебральной ишемии и нейропротекция. Вестник РАМН. 2003. № 11 . С. $74-80$.

32. Stadnik S.M., Saiko O.V., Hayda I.V. Immunological aspects in the acute period of ischemic stroke. Міжнародний неврологічний журнал. 2020. Т. 16. № 5. C. 18-25. DOI: 10.22141/22240713.16.5.2020.209247. 
33. Кашаева Л.Н., Карзакова Л.М., Саперов В.Н. Иммунологические нарушения при церебральных инсультах и их коррекция. Медицинская иммунология. 2005. Т. 7. № 1. С. 57-62. DOI 10.15789/1563-0625-2005-1-57-62.

34. Королева Е.С., Бразовская Н.Г., Левчук Л.А. и др. Оценка уровней нейронспецифической енолазы и мозгового нейротрофического фактора на этапах реабилитации в остром и раннем восстановительном периодах ишемического инсульта. Журнал неврологии и психиатрии им. С. С. Корсакова. Спецвыпуски. 2020. T. 120. № 8. C. 30-36. DOI 10.17116/jnevro202012008230.

\section{Information about the authors: Stepanenko I. V.,}

Doctor of Medical Sciences, Associate Professor, Chief of the Department of Neurorehabilitation Romodanov Neurosurgery Institute of the National Academy of Medical Sciences of Ukraine 32, Platona Mayborody str., Kyiv, 04050, Ukraine

Popova I. Yu., Candidate of Medical Sciences, Doctor at the Department of Neurorehabilitation Romodanov Neurosurgery Institute of the National Academy of Medical Sciences of Ukraine 32, Platona Mayborody str., Kyiv, 04050, Ukraine 